\title{
INFLUENCE OF USING FLAVOMYCIN AND PROPOLIS AS FEED ADDITIVES ON BUFFALO MILK PRODUCTION, AND GROWTH PERFORMANCE AND BLOOD METABOLITES OF SUCKLING CALVES
}

\author{
M. Abd-Allah ${ }^{1}$ and M. W. H. Daghash ${ }^{2}$ \\ ${ }^{1}$ Department of Animal Production, Faculty of Agric. Al-Azhar Univ, Assiut Branch, Assiut, Egypt. \\ ${ }^{2}$ Department of Animal Production, Faculty of Agric. Assiut Univ, Assiut, Egypt.
}

E-mail: mohtaram_a_m_e@yahoo.com,muhtaram@azhar.edu.eg.

(Received 8/1/2019, accepted 26/2/2019)

\section{SUMMARY}

$\mathrm{T}$ his research was conducted to elucidate the effect of flavomycin ${ }^{\circledR}$ and propolis powder, as feed additives, on milk yield of buffalo and productive performance of suckling calves such as total body weight, average daily gain, body measurements and selective metabolic parameters. For this reason, sixteen multiparous Egyptian buffalo with an initial body weight of $445 \pm 11.45 \mathrm{~kg}$. and their offspring suckling calves (16 calves) were used in this experiment. The trial was started at 6 weeks prenatal pregnancy and 4 months after parturition (suckling period) till weaning. The animals (mother and their suckling calves) were divided into four equal groups (4 animals / each group) according the preceding lactation season. First group (CO) was fed on the diet without any additives. Second group (T1) was fed on the diet $+50 \mathrm{mg}$ of propolis/head / day. Third group (T2) was fed on the diet $+60 \mathrm{mg}$ of flavomycin/ head/ day, while fourth group (T3) was fed on the diet $+50 \mathrm{mg}$ of propolis $+60 \mathrm{mg}$ flavomycin / head / day. The buffaloes were fed on a concentrated diet consisting of $45 \%$ seed, $15 \%$ cotton seed, $15 \%$ soy bean, $22 \%$ wheat bran, $1 \%$ premix salts, $1 \%$ limestone and $1 \%$ salt while suckling calves were allocated with their mothers and fed colostrum for the first three days. Milk, starter and treatments were given to suckling calves till weaning. The amount of buffalo milk were estimated. Body weight, body measurements and blood samples were taken from newborn calves. Results revealed that productive performance and selective blood metabolites were affected by supplemented diets. Daily and total milk yield were increased insignificantly in animals fed treated diets than untreated ones. There was a significant improvement of daily and final body weight $(\mathrm{P}<0.05)$ in the suckling calves treated with propolis alone or combined with flavomycin until the weaning period. Final chest girth, body high and abdominal circumference (AC) measurements were increased insignificantly for calves treated with propolis. There was a tendency of higher concentration of total protein in plasma of calves fed flavomycin (T2) than those fed control diets. Concentration of albumin was decreased insignificantly $(\mathrm{P}>0.05)$ in treated calves compared with control. Furthermore, flavomycin in the diets (T2) increased total globulin insignificantly $(\mathrm{P}>0.05)$ by about $29 \%$ compared with the control group. Treated diets induced the lowest levels in the plasma triglyceride and total cholesterol $(\mathrm{P}<0.01)$ in comparison to the control diets. Concentration of glucose was decreased $(\mathrm{P}<0.05)$ while transaminases enzyme levels were increased $(\mathrm{P}<0.05)$ in treated calves compared with untreated ones. It could be concluded that added flavomycin and /or propolis in the diets increased milk yield and improved live body weight and growth in suckling calves with improvement in final chest girth, body high and abdominal circumference measurements. Selected blood plasma metabolites affected by dietary treated diets without any harmful effect on health of suckling claves.

Keywords: Flavomycin, propolis, milk production, blood metabolites, Egyptian buffalo and calves.

\section{INTRODUCTION}

Suckling period is considered the most important period in new born calves' life. Moreover, the reproductive efficiency of herd depends on livability of suckling calves. Calves that are cared well, have a less cost to rear, grow faster, go on to be stronger and decease risk of disease. Webster, (1986) reported that in early ages of calves, the better growth performance made it possible to utilize them as a brood-stock. He added that the unproductive period would be shorten and the income of farm would increase gradually when employing the suckling calves as a brood-stock. In order to reach the target, various methods can be utilized 


\section{Abd-Allah and Daghash}

to improve productive performance as energy-protein rates, hormones and feed additives for feeding calves (Thickett et al., 1988). Such methods are not accepted by consumer because of their inversely effect on human health. Then, ruminant nutritionists have developed many natural methods such as the use of antibiotic growth promoters to enhance production by limiting the effects of pathogenic infection on ruminant productivity (Valero et al., 2014).

Flavomycin is an antibiotic that promotes growth in ruminant and non-ruminant livestock. Flavomycin is a trade name of the antibiotic growth promoter "Flavophosholipol" (Bauer and Dost, 1974). Flavomycin is used as feed additive to promote the growth in ruminant (El-Basiony, 1994), no residues are left in the meat since they are not absorbed from the alimentary tract due to their high molecular size (Hudd, 1983). Van der Merwe et al., (2001) reported that, cows fed diets supplemented with flavomycin improved fiber digestion and increased milk production. In lambs, Heydari et al., (2008) illustrated that, weight gain and feed conversion ratio improved while dry matter intake depressed due to fed flavomycin in the diet. Added flavomycin to the diets can improved cellulose digestion by inhibition the growth of lactate- producing bacteria as reported by Matabudul et al., (2001).

Propolis may be used as a feed additive in animal production and meet current consumer expectations about safety and toxicity of animal products. Propolis is a natural bee product, it is rich in plant phenolic compounds that confer important biological properties such as antibacterial actions, cytostatic, hepatoprotective activities (Banskota, et al.,2000), antimicrobial, anti-inflammatory, immunomodulatory properties (Bankova et al., 2000), antioxidant, antibacterial (Marcucci et al., 2001), antibiotic (Cottica et al., 2011), antiparasitic and antiseptic properties in its structure is antiviral (Vynograd, et al., 2000), antifungal (Ota, et al., 2001), analgesic and tissue regenerative (De Castro, 2001). In addition, Stangaciu, (1999) reported the positive effects and preventive properties of propolis on dangerous pathogenic bacteria's and viral infections. The beneficial effect of propolis on immune response and growth performance in both broiler (Ziaran et al., 2005) and layer (Galal et al., 2008) have been reported.

It can be proposed that the combination of propolis and flavomycin could be of particular benefit and be useful as a substitute for antibiotics. There are a little reported studies about the combined effects of natural substance (propolis) and antibiotic (flavomycin ${ }^{\circledR}$ ) on body performance and physiological parameters of Egyptian buffalo and their calves. Therefore the present study was carried out to elucidate the effect of a combination of propolis and flavomycin on milk yield, body measurements and some blood metabolites of Egyptian buffalo and suckling calves.

\section{MATERIALS AND METHODS}

The present study was carried out at the Animal production Farm, Department of Animal Production, Faculty of Agriculture, Assiut Banch, Al-Azher University. The objective of this study was to elucidate the effect of flavomycin ${ }^{\circledR}$ and propolis powder, as feed additives, on milk yield of buffalo and productive performance of suckling calves such as total body weight, average daily gain, body measurements and selective metabolic parameters.

\section{Experimental animals:}

Sixteen multiparous Egyptian buffalo with an initial body weight of $445 \pm 11.45 \mathrm{~kg}$ and their offspring suckling calves ( 16 calves) were used in this study. The trial was started at 6 weeks prenatal pregnancy and 4 months after parturition (suckling period). The animals (mother and their calves) were randomly allocated into four equal groups according to the preceding lactation (four animals each). First group (CO) was fed on the diet without any additives. Second group (T1) was fed on the diet $+50 \mathrm{mg}$ of propolis/head/day. Third group (T2) was fed on the diet $+60 \mathrm{mg}$ of flavomycin/head/day while fourth group (T3) was fed on the diet $+50 \mathrm{mg}$ of propolis $+60 \mathrm{mg}$ flavomycin/head/day. The buffaloes were fed on a concentrate feed mixture diet consisting of $45 \%$ seed, $15 \%$ cotton seed, $15 \%$ soy bean, $22 \%$ wheat bran, $1 \%$ premix salts, $1 \%$ limestone and $1 \%$ salt. The diet was served twice a day, as well as feeding on clover during the day. Propolis was purchased from traders specialized in the sale of bee products in Assiut Governorate, after the quality test for selecting the best by the bee researchers in the Department of Plant Protection in the same Faculty. After purchasing the amount of propolis required for the experiment and purified from any impurities was well grinded with the coffee mill and was saved in bags of polyethylene until use. Propolis powder was mixed with concentrate feed thoroughly and used in the respective groups' calves. The amount required for 
each animal from flavomycin was weighed on an electronic balance and placed in capsules to give to each individual animal. Suckling calves were allocated with their mothers and fed colostrum for the first three days. After that milk, starter and treatments were given to suckling calves till weaning. All calves were weaned at the end of the $4^{\text {th }}$ month. Wheat straw were given ad libitum to calves after the second weeks, fresh and clean water was provided from the first week.

\section{Measurements:}

The amount of mother's milk was estimated once a month each time until weaning. Calves were allocated with their mothers and fed colostrum for the first three days after the birth. After that, newborn calves were given milk and starter as well as treated with flavomycin and propolis during the experimental period. Body weight of suckling calves in trial were weighted after 24 hours of parturition and then every two weeks till the end of research (at the $4^{\text {th }}$ month) and average daily gain was also calculated. Also body measurements (body length, chest girth, body high and abdominal circumference) were recorded conjugated with body weight and average daily gain.

\section{Blood metabolites:}

At the end of the experiment at $4^{\text {th }}$ month of age, blood samples were taken from calves and collected into in a tube containing EDTA to prevent clotting. Blood plasma was then separated by centrifugation for $15 \mathrm{~min}$ at $3000 \mathrm{rpm}$. Plasma was subsequently decanted into glass vials and stored at $-20^{\circ} \mathrm{C}$ until analysis. The frozen samples were allowed to thaw at room temperature prior to analysis. Concentrations of total protein, albumin, triglyceride, total cholesterol and the activity of aspartate transaminase (AST) and alanine transaminase (ALT) were determined in blood plasma by using a biochemical analyzer kits. Plasma total globulin was obtained by the difference between albumin and total protein and albumin/globulin (alb/glo) ratio was calculated.

\section{Statistical analysis:}

Data were subjected to a one-way analysis of variance with treatment group effect using the General Linear Model (GLM) procedure of SAS (2004). Significant differences betwetreatment means were determined using Duncan's new multiple-ranges test (Duncan, 1955).

\section{RESULTS AND DISCUSSION}

\section{Milk production:}

Data of Table (1) showed that T2 had lowest $(\mathrm{P}<0.05)$ monthly, total and average daily milk yield when compared to T1, T3 and control groups. Furthermore, fed propolis and flavomycin supplemented diets (T3) resulted in insignificantly highest $(\mathrm{P}>0.05)$ monthly, total and average daily milk yield when compared to other treatments. Flavomycin has a marked antibacterial effect on numerous gram-positive micro-organisms

Table (1): Effect of treatments on milk yield of Egyptian buffalos.

\begin{tabular}{lcccccc}
\hline Item & CO & T1 & T2 & T3 & \pm SEM & Sig \\
& & & & & & \\
\hline $1^{\text {st }}$ month & $262.8^{\mathrm{a}}$ & $241.3^{\mathrm{a}}$ & $195.7^{\mathrm{b}}$ & $272.8^{\mathrm{a}}$ & 13.75 & $* *$ \\
$2^{\text {nd }}$ month & $249.4^{\mathrm{a}}$ & $240.1^{\mathrm{a}}$ & $178.6^{\mathrm{b}}$ & $251.2^{\mathrm{a}}$ & 14.09 & $* *$ \\
$3^{\text {rd }}$ month & $221.4^{\mathrm{a}}$ & $228.5^{\mathrm{a}}$ & $149.65^{\mathrm{b}}$ & $242.7^{\mathrm{a}}$ & 14.30 & $* *$ \\
Total milk yield (TMY) & $733.6^{\mathrm{a}}$ & $709.9^{\mathrm{a}}$ & $524.0^{\mathrm{b}}$ & $766.7^{\mathrm{a}}$ & 40.35 & $* *$ \\
Average daily milk yield (ADMY) & $8.15^{\mathrm{a}}$ & $7.89^{\mathrm{a}}$ & $5.82^{\mathrm{b}}$ & $8.52^{\mathrm{a}}$ & 0.448 & $* *$ \\
\hline
\end{tabular}

(a-b) Means values with different superscripts within a row differ significantly $(p<0.05)$. CO: Control diet without additives. T1: Fed control ration plus $50 \mathrm{mg}$ propolis head/day. T2: Fed control ration plus $60 \mathrm{mg}$ flavomycin head/day. T3: Fed control ration plus $50 \mathrm{mg}$ propolis and $60 \mathrm{mg}$ flavomycin /head/day. SEM: standard error of means. 
that are found in the digestive tract, and enhances the breakdown of starch and cellulose in the rumen resulting in increased propionic and acetic acid production (Cafantaris, 1981). The addition of flavomycin to the diet of cows calving during early summer onto kikuyu (Pennisetum clandestinum) pasture would facilitate fiber digestion leading to improved milk production and composition as reported by van der Merwe et al., (2001). A reduction in the ammonia content of the rumen has also been reported to result from flavomycin supplementation (Murray et al., 1990) and this is an indication of increased microbial protein synthesis (Van der Bergh, 1995) could be help to improved milk production and composition .

\section{Growth performance:}

Results of Table (2) showed that the initial body weight was equal among the experimental calves without any significant differences. Compared with the control group, the data cleared that there was a significant improvement $(\mathrm{P}<0.05)$ in the calves treated with propolis alone or combined with flavomycin until the weaning period. At first and second month of age, T2 group which treated with flavomycin exhibited a significant increase $(\mathrm{P}<0.05)$ in body weight by $8.91 \%$ and $9.66 \%$, respectively compared with a control ones. At the third and weaning period, total body weight was increased significantly $(\mathrm{P}<0.05)$ by about $11.37 \%$ and $10.76 \%$, respectively in calves fed diets supplemented with propolis and flavomycin compared with fed control diets. Furthermore, at suckling (4 months) average daily gain was increased in treated calves. At $2^{\text {th }}$ and $3^{\text {th }}$ month of age calves fed diets containing experimental diets showed higher $(\mathrm{P}<0.01)$ average daily gain than those fed the control diet, while T3 and T2 groups had higher $(\mathrm{P}<0.01)$ average daily gain by about $27.92 \%$ and $48.55 \%$ compared with control ones, respectively.

Table (2): Effect of treatments on body weight and average daily gain of Egyptian buffalo calves.

\begin{tabular}{|c|c|c|c|c|c|c|}
\hline Item & $\mathrm{CO}$ & $\mathrm{T} 1$ & $\mathrm{~T} 2$ & T3 & $\pm \mathrm{SEM}$ & Sig \\
\hline \multicolumn{7}{|c|}{ Body weight (kg) } \\
\hline Birth weight & 36.26 & 36.83 & 37.62 & 37.476 & 1.31 & NS \\
\hline $1^{\text {st }}$ month & $54.17^{\mathrm{b}}$ & $55.15^{\mathrm{ab}}$ & $59.00^{\mathrm{a}}$ & $55.33^{\mathrm{ab}}$ & 1.25 & $*$ \\
\hline $2^{\text {nd }}$ month & $65.50^{\mathrm{b}}$ & $68.17^{\mathrm{ab}}$ & $71.83^{\mathrm{a}}$ & $69.83^{\mathrm{ab}}$ & 1.50 & $*$ \\
\hline $3^{\text {rd }}$ month & $77.67^{\mathrm{b}}$ & $86.00^{\mathrm{a}}$ & $85.33^{\mathrm{ab}}$ & $86.50^{\mathrm{a}}$ & 1.52 & $*$ \\
\hline Weaning weight & $86.97^{\mathrm{b}}$ & $94.67^{\mathrm{a}}$ & $93.33^{\mathrm{ab}}$ & $96.33^{\mathrm{a}}$ & 1.42 & $*$ \\
\hline \multicolumn{7}{|c|}{ Average daily gain (g) } \\
\hline $1^{\text {st }}$ month & 596.9 & 712.8 & 610.6 & 595.2 & 19.42 & NS \\
\hline $2^{\text {nd }}$ month & $377.8^{c}$ & $427.8^{\mathrm{b}}$ & $433.9^{b}$ & $483.3^{\mathrm{a}}$ & 13.56 & $* *$ \\
\hline $3^{\text {rd }}$ month & $405.6^{\mathrm{c}}$ & $450.0^{\mathrm{b}}$ & $594.4^{\mathrm{a}}$ & $555.6^{\mathrm{a}}$ & 13.11 & $* *$ \\
\hline Weaning weight & 310.0 & 266.7 & 288.9 & 327.8 & 17.20 & NS \\
\hline
\end{tabular}

The increase in body weight and body weight gain in treated calves agree with Hassan, (2009). who reported that flavomycin additions increased the final body weight and body weight gain of lambs. Corlateanu (1976) found that calves treated with propolis have better growth performance than calves in control group. Besides, Hegazi and Abd El-Hady (1996) reported that propolis has positive effect on growth of livestock. Denli et al., (2005) found that the addition of propolis at $0.5,1$ or $1.5 \mathrm{~g} / \mathrm{kg}$ in the diet significantly increased growth parameters of quail chicks such as body weight gain and feed consumption and improved feed efficiency compared with controls and gave similar effects to that of flavomycin on body weight gain during a 35 day feeding period. Yucel et al., (2015) illustrated that propolis had significant effect on female calves for total and daily weight gain $(\mathrm{P}<0.05)$, there was no significant difference between control and propolis groups for male calves. In contrast, Jack et at., (1986) found no significant effect on live weight gain of calves fed diets containing antibiotics up to the age of 84 days. Economides, et al., (1988) showed no difference in body weight when diets of male and female lambs were treated with Flavomycin. In this field, Sarker and Yang (2010) found lowest weight observed in propolis fed calves.

Improving the live body weight and body daily gain may be due to good effect of flavomycin on lambs health and improving cellulose digestion of diets high in readily available carbohydrate by inhibition the growth of lactate- producing bacteria (Matabudul et al., 2001). Furthermore, flavomycin significantly improved gross energy digestibility in the ileum and fat digestibility both in the ileum and total intestinal 
tract (Sharifi et al., 2012) leading to significant improved in claves growth. The beneficial effect of propolis on growth performance in suckling calves may be act as an antioxidant (Cottica et al., 2011) and antimicrobial (Bankova et al. 2000) leading to decreased growth of pathogenic bacteria responsible for growth depression resulted in better intestinal health and improved digestion and absorption.

\section{Body measurements:}

Supplementing the suckling calves' diet with propolis and flavomycin affect body measurements (Table 3). At $1^{\text {st }}$ month of age body length was lower $(\mathrm{P}<0.05)$ in treated calves than control group. At birth period, abdominal Circumference was higher significantly $(\mathrm{P}<0.05)$ by about $9.42 \%$ in $\mathrm{T} 1$ group than $\mathrm{CO}$ ones. Final chest girth, body high and AC measurements were higher insignificantly for calves treated with propolis. Yucel et al. (2015) observed higher body measurements in propolis group compared with control group. They added that final body length was 74.66 and $77.74 \mathrm{~cm}$ for female calves, respectively. They added that, chest perimeter both in females and males was higher in control group compared with propolis group (respectively for propolis and control group $90.31 \mathrm{~cm}$ versus $92.29 \mathrm{~cm}$ in females, $94.49 \mathrm{~cm}$ versus $95.14 \mathrm{~cm}$ in males). Chest depth was particularly higher in control group for females $(31.00 \mathrm{~cm}$ versus 30.99 $\mathrm{cm})$, higher in propolis group for males $(31.67 \mathrm{~cm}$ versus $32.74 \mathrm{~cm})$.

Table (3): Effect of treatments on body measuerments of buffalo calves.

\begin{tabular}{|c|c|c|c|c|c|c|}
\hline \multirow{2}{*}{ Age } & \multicolumn{4}{|c|}{ Treatments } & \multirow{2}{*}{$\pm \mathrm{SEM}$} & \multirow{2}{*}{ Sign } \\
\hline & $\mathrm{CO}$ & $\mathrm{T} 1$ & $\mathrm{~T} 2$ & T3 & & \\
\hline \multicolumn{7}{|c|}{ Body length $(\mathrm{cm})$} \\
\hline At birth & $49.67^{b}$ & $53.67^{\mathrm{ab}}$ & $56.33^{\mathrm{a}}$ & $53.00^{\mathrm{ab}}$ & 1.41 & $*$ \\
\hline At 1 month & $71.61^{\mathrm{a}}$ & $64.00^{\mathrm{b}}$ & $64.00^{\mathrm{b}}$ & $63.33^{\mathrm{b}}$ & 1.93 & $*$ \\
\hline At 2 month & 74.666 & 73.00 & 74.333 & 73.00 & 1.55 & NS \\
\hline At 3 month & 80.33 & 77.67 & 80.00 & 78.33 & 1.32 & NS \\
\hline At weaning & 80.67 & 79.33 & 82.33 & 79.67 & 1.13 & NS \\
\hline \multicolumn{7}{|c|}{ Chest girth $(\mathrm{cm})$} \\
\hline At birth & 72.00 & 76.33 & 75.67 & 73.67 & 1.41 & NS \\
\hline At 1 month & 87.33 & 90.33 & 86.00 & 85.67 & 2.06 & NS \\
\hline At 2 month & 97.00 & 100.00 & 93.666 & 93.000 & 2.65 & NS \\
\hline At 3 month & 103.67 & 107.33 & 101.67 & 99.33 & 2.92 & NS \\
\hline At weaning & 106.00 & 110.00 & 108.00 & 104.00 & 3.03 & NS \\
\hline \multicolumn{7}{|c|}{ Body high $(\mathrm{cm})$} \\
\hline At birth & 74.33 & 75.67 & 75.33 & 78.33 & 2.48 & NS \\
\hline At 1 month & 88.67 & 87.00 & 84.67 & 84.00 & 1.57 & NS \\
\hline At 2 month & 94.500 & 95.666 & 91.500 & 92.00 & 2.48 & NS \\
\hline At 3 month & 98.500 & 101.33 & 97.167 & 96.50 & 2.08 & NS \\
\hline At weaning & 99.17 & 103.67 & 101.67 & 99.17 & 2.03 & NS \\
\hline \multicolumn{7}{|c|}{ Abdominal Circumference $(\mathrm{cm})$} \\
\hline At birth & $74.33^{\mathrm{b}}$ & $81.33^{\mathrm{a}}$ & $79.67^{\mathrm{ab}}$ & $78.00^{\mathrm{ab}}$ & 1.83 & $*$ \\
\hline At 1 month & 93.16 & 96.00 & 91.67 & 90.67 & 1.82 & NS \\
\hline At 2 month & 103.333 & 106.333 & 99.666 & 98.333 & 2.33 & NS \\
\hline At 3 month & 114.33 & 118.00 & 113.33 & 109.66 & 4.22 & NS \\
\hline At weaning & 117.00 & 123.33 & 119.00 & 114.67 & 3.64 & NS \\
\hline
\end{tabular}

\section{Blood plasma metabolites:}

\section{Total protein and its fractions:}

Concentrations of total protein, albumin and total globulin as well as albumin/globulin ration in blood plasma of calves as affected by the experimental diets are presented in Table (4). Data revealed that the experimental diets did not affect total protein and its fractions in blood plasma of treated calves. There was a 
tendency of higher concentration of total protein in plasma of calves fed flavomycin (T2) than those fed control diets. Concentration of albumin was decreased insignificantly $(\mathrm{P}>0.05)$ in treated calves compared with control. Furthermore, flavomycin in the diets (T2) increased total globulin insignificantly $(\mathrm{P}>0.05)$ by about $29 \%$ compared with a control group.

The important of total protein come from that protein has role in intracellular buffers within body tissues to provide a reserve buffering capacity and the increase in total protein could be attributed to improvement in synthesis and digestion of crude protein due to flavomycin administration. Average values of serum total protein, albumin and globulin were significantly $(\mathrm{p}<0.05)$ increased with addition flavomycin to lamb diets as reported by Abdel-Monemm (2013). Similar results were obtained by El-Ashry et al.,(2003), who found that supplemented flavomycin increased $(\mathrm{P}<0.01)$ total serum protein more than the control

The increase in total protein in the present study could be attributed to improvement in synthesis and digestion of crude protein due to flavomycin administration. Also, the increase in globulin level with increasing flavomycin levels could be attributed to the improved immunity of suckling calves, through the better efficacy of the liver to synthesize enough globulins for immunological action (Harper et al., 1977). It is interest to note that albumin/globulin ratio gives a decrease in production of albumin by the liver reflecting normal hepatic function.

\section{Triglyceride and total cholesterol concentrations:}

Propolis (T1) and flavomycin (T2) in the diets induced the lowest levels in triglyceride in blood plasma significantly $(\mathrm{P}<0.01)$ by about $33.37 \%$ and $33.13 \%$, respectively in comparison to the control diets (Table 4). It is very important to cleared that supplementation with treated diets decreased total cholesterol in blood plasma significantly $(\mathrm{P}<0.01)$ by about $25.63 \%, 38.96 \%$, and $26.84 \%$, respectively compared with untreated diets.

Table (4): Effects of antibiotic and propolis as feed additives on blood components of Egyptian buffalo calves.

\begin{tabular}{lcccccc}
\hline Item & CO & T1 & T2 & T3 & \pm SEM & P \\
& & & & & & \\
\hline Total protein (g/dl) & 7.27 & 6.86 & 7.42 & 6.59 & 0.58 & NS \\
Albumin (g/dl) & 4.13 & 3.85 & 3.37 & 3.58 & 0.42 & NS \\
Total globulin (g/dl) & 3.14 & 3.02 & 4.05 & 3.01 & 0.52 & NS \\
A/g ratio & 1.54 & 1.47 & 1.32 & 1.61 & 0.37 & NS \\
Triglyceride (mg/dl) & $156.86^{\mathrm{a}}$ & $117.61^{\mathrm{b}}$ & $117.82^{\mathrm{b}}$ & $162.26^{\mathrm{a}}$ & 11.34 & $* *$ \\
Total cholesterol (mg/dl ) & $194.96 \mathrm{a}$ & $144.99^{\mathrm{b}}$ & $119.01^{\mathrm{b}}$ & $142.62^{\mathrm{b}}$ & 12.95 & $* *$ \\
Glucose (mg/dl ) & $137.58^{\mathrm{a}}$ & $103.94^{\mathrm{ab}}$ & $103.94^{\mathrm{ab}}$ & $91.11^{\mathrm{b}}$ & 12.12 & $*$ \\
ALT (IU/dl) & $49.22^{\mathrm{b}}$ & $57.11^{\mathrm{a}}$ & $52.89^{\mathrm{ab}}$ & $49.89^{\mathrm{b}}$ & 2.24 & $*$ \\
AST (IU/dl ) & $17.78^{\mathrm{ab}}$ & $12.67^{\mathrm{b}}$ & $21.33^{\mathrm{a}}$ & $17.11^{\mathrm{ab}}$ & 2.47 & $*$ \\
\hline
\end{tabular}

(a-b) Means values with different superscripts within a row differ significantly ( $p<0.05)$. CO: Control diet without additives. T1: Fed control ration plus $50 \mathrm{mg}$ propolis /head/day. T2: Fed control ration plus $60 \mathrm{mg}$ flavomycin head/day. T3: Fed control ration plus $50 \mathrm{mg}$ propolis and $60 \mathrm{mg}$ flavomycin /head/day. SEM: standard error of means.

The hypolipidemic and hypocholosterolemic effects of flavomycin and propolis are probably related to the decrease in dietary cholesterol absorption or increased primary bile acid synthesis and /or through its fecal losses. The decrease in the cholesterol level in the treated groups could be attributed to the fact that propolis might not be interfered with HDL-c synthesis but its mode of action might be induced by inhibiting cholesterol biosynthesis through inhibiting of HMG-CoA reductase, the rate-limiting enzyme that mediates the first step in cholesterol biosynthesis (Albokhadaim, 2015). Cholesterol is transported via blood by lipoprotein-c (bad cholesterol) does it in the opposite direction. Therefore, decrease in serum LDL-c cholesterol is an indication of low rate of transportation of cholesterol from liver to tissues and subsequent transformation of cholesterol into bile acid by liver enzyme (El-Beshbishy et al., 2006). Kolankaya et al., (2002) observed that there were an increases in HDL level and decreases in LDL level in the Turkish propolis treated group compared to the alcohol group. They suggest that these effects are protective against degenerative diseases and against alcohol-induced oxidative stress via free radicals. 


\section{Glucose concentration:}

Table (4) showed that claves of T3 group had the lowest $(\mathrm{P}<0.05)$ plasma glucose level compared with the control but did not differ significantly from the other treatments. Concentrations of blood glucose decreased by about $24.45 \%, 24.45 \%$ and $33.78 \%$ in T1, T2 and T3 groups compared to control ones, respectively.

Propolis-ethanol extract has a beneficial effect on reduction of blood sugar levels in alloxan-induced diabetes rabbits as reported by Wang (2004). Furthermore, many studies showed that propolis and/or one of its active components reduced blood sugar level in experimental diabetic animals and modulated the metabolism of blood lipids leading to decreased lipid peroxidation and scavenge the free radicals (El-Sayed et al., 2009). In contrast, serum glucose level was significantly $(\mathrm{P}<0.05)$ increased in flavomycin quail group compared with control and propolis groups as reported by (Denli et al., 2005).

\section{Liver function:}

Activity of alanine transaminase (ALT) and aspartate transaminase (AST) in blood plasma of calves as affected by experimental diets are presented in Table (4). Calves of T1 group had the highest $(\mathrm{P}<0.05)$ ALT concentration compared to T3 and CO groups. While T2 group had the highest $(\mathrm{P}<0.05)$ AST concentration compared to T1 treated calves, but this increase is still within normal range reported by numerous authors. Data concerning AST and ALT may also pointed out to the healthy moderate self- excitation to the liver for excretion of transaminase liver enzymes for better metabolism. Abdel-Monemm (2013) showed insignificant effect of buffalo and sheep rations supplemented with flavomycin on liver enzymes. Denli et al. (2005) illustrated that there was an increase in AST and ALT activities of birds fed with flavomycin compared to the control. They added that, the supplementation of propolis in diet caused a reduction in these enzyme activities compared to flavomycin group. Based on this result, propolis may have hepatoprotective effects or play a role in the prevention of liver injury. Hafez et al. (1983) and Abdel-Hamid et al. (1999), stated that ALT and AST secretions are accelerators to the rate of metabolism and protein biosynthesis in order to meet the increased requirements to synthesis new tissues.

\section{CONCLUSION}

It could be concluded from the previous results that added flavomycin and /or propolis in the diets increased milk yield and improved live body weight and growth in suckling calves with improvement in chest girls, body high and abdominal circumference measurements. In addition, propolis and flavomycin during the growth period showed similar effects on growth performance. Selected blood metabolites were affected by dietary treated diets without any harmful effect on health of suckling claves. Therefore, it may serve as a natural substitute for antibiotics in suckling calves diets.

\section{REFERENCES}

Abdel-Hamid, A.M., E.I. Shehata and M.E. Ahmed (1999). Physionutritional studies on pregnant and lactating goats fed on rations differing in roughage /concentrate ratio at different feeding levels and or not supplemented with bentonite: Effects on the blood profile .J.Agric .Sci, Mansoura Univ., 24(9): 4587.

Abdel-Monemm, U.M. (2013). Effect of Dietary Supplementation of Flavomycin on the Growth Performance, Digestibility Traits, Carcass Characteristics, Carcass Meat Chemical Analysis and Some Blood Components of Lambs. Australian Journal of Basic and Applied Sciences, 7(1): 589-594.

Albokhadaim, I. (2015). Influence of dietary supplementation of propolis on hematology, biochemistry and lipid profile of rats fed high cholesterol diet. Journal of Advanced Veterinary and Animal Research, (2): 56-63.

Bankova V., R. Christov., M.C. Marcucci., S, Popov (1998). Constituents of Brazilian geopropolis. Z Naturforsch 53c: 402-406. 
Banskota, A.H., Y. Tezuka., I.K. Adnyana., K. Midorikawa., K. Matsushige.,D. Message., A.A. Huertas and S. Kadota (2000). Cytotoxic, hepatoprotective and free radical scavenging effects of propolis from Brazil, Peru, the Netherlands and China. J. Ethnopharmacol., 72: 239-246.

Bauer, F. and G. Dost (1974). Flavomycin, the first antibiotic intended exclusively as a food supplement. Farbwerke Hoechst. AFrankfurta Main. Hoechst, 87-92.

Cafantaris, B. (1981). Uber die wirkung von antibiotika-zusatzenauf die mikrobielle garung im pansensaft in vitro (The effect of antibiotic additives on the microbial fermentation in rumen fluid in vitro). AgrarDiss., Universitat Hohenheim.

Corlateanu, D. (1976). Treatment with bee products of neonatal calves, $2^{\text {nd }}$ Int. Symposium on Apitherapy, Bucharest, September $2^{\text {nd }}-7^{\text {nd }}$, Romania, 295-297.

Cottica, S.M., A.C.H.F. Sawaya., M.N. Eberlin., S.L. Franco., L.M. Zeoula., J.V. Visenteiner (2011). Antioxidant activity and composition of propolis obtained by different methods of extraction. J. Braz. Chem. Soc. 22, 929-935.

De Castro, S.L. (2001). Propolis: Biological and pharmacological activities. Therapeutic uses of this bee product. Annu. Rev. Biomed. Sci., 3: 49-83.

Denli, M., S. Cankaya, S. Silici1., F. Okan and A.N. Uluocak (2005). Effect of Dietary Addition of Turkish Propolis on the Growth Performance, Carcass Characteristics and Serum Variables of quail (Coturnix coturnix japonica). Asian-Aust. J. Anim. Sci, 18(6):848-854.

Duncan, D.B.(1955). Multiple range and multiple F tests. Biometrics 11, 1-42.

Economides, S., E. Georghiades, Ch. Papachristoforou and M. Hadjipanayiotou (1988). The effect of feed antibiotics and of vitamin A on the performance of Chois lambs and Friesian calves. Technical Bulletin 101.

El-Ashry, M.A., Afaf, M. Fayed., K.M.Youssef., F.A. Salem and G.M. Abdul-Aziz (2003). Effect of feeding flavomycin or yeast as feed supplement on lambs' performance in Sinai. Egypt. J .Nutr. and Feeds, 10091022.

El-Basiony, A.Z. (1994). Performance of growing lambs and buffalo calves given flavomycin as feed supplement. Annuals of Agric. Sci., Moshtohor, 32(4):1511-1520.

El-Beshbishy, H.A., A.N. Singab., J. Sinkkonen and L. Pihlaja (2006). Hypolipidemic and antioxidant effect of Morus Alba L. (Egyptian mulberry) root bark fractions supplementations in cholesterol fed rats. Life Sc., (78): 2727-2733.

El-Sayed, M.E, O.M. Abo-Salem., H.A Aly, A.M. Mansour (2009). Potential Antidiabetic and Hypolipidemic effects of propolis extract in STZ-induced diabetic Rats. Pak, J. Pharm Sci., (22):168-74.

Galal, A., A.M.H. Ahmed., W.A.H. Ali., M.H. Elsanhoury., H.E. Ahmed (2008). Residual feed intake and its effect on cell-mediated immunity in laying hens given different propolis levels. International Journal of Poultry Science 7, 1105-1111.

Hafez, A.M., H. Ibrahim, A. Gomaa, A.A. Farrag and I.A. Salem (1983). Enzymatic and heamatological studies on buffalo's preparturient periods. Assiut Vet. Med. J., 11(21): 172.

Harper, H.A., V.W. Rodwell and P.A. Mayer (1977). Review of physiological chemistry, $6^{\text {th }}$ (Eds.) Lange Medical Publication, California.

Hassan, E.A.S. (2009). Utilization of growth promoters and bentonite in sheep rations. Ph.D Thesis, Faculty of Agriculture, Al-Azhar University.

Hegazi A.G. and F. Abd El-Hady (1996). Influence of administration of propolis on chicken immune status. The Egyptian Journal of Immunology, 3(1):111-116.

Heydari, K.H., N. Dabiri, J. Fayazi and H. Roshanfekr (2008). Effect of Ionophores Monensin and Lasalocid on Performance and Carcass Characteristics in Fattening Arabi Lambs. Pakistan Journal of Nutrition, 7(1): $81-84$

Hudd, D.L. (1983). Pharmacological Basis of Large Animal Medicine. Oxford, Mlack well, (107-128). 
Jack, E.M.Et., R.J. Fallon., F.J. Harte and M.J. Drennan (1986). Effect of avoparcin, flavomycin and monensin sodium inclusion in a calf concentrate diet on calf performance. Irish Journal of Agricultrural Research 25: 197-204.

Kolankaya, D., G. Selmanoğlu., K. Sorkun and B. Salih (2002). Protective effects of Turkish propolis on alcohol-induced serum lipid changes and liver injury in male rats. Food Chemistry, 78, 213-217.

Marcucci, M.C., F. Ferreres., C. García-Viguera., V.S. Bankova., S.L. De Castro., A.P. Dantas., P.H.M. Valente and N. Paulino (2001). Phenolic compounds from Brazilian propolis with pharmacological activities. J. Ethnopharmacol. 74, 105-112.

Matabudul, D.K., B. Conway., I. Lumley and S. Sumar (2001). The simultaneous determination of the ionophore antibiotics in animal tissue and eggs by tandem electrospray LC-MS-MS. Food Chem., 75: 345-354.

Murray, P.J., J. B. Rowe and E. M. Aitcheson (1990). The influence of protein quality on the effect of flavomycin on wool growth, live weight change and rumen fermentation in sheep. Aust. J. Agric.

Ota, C., C. Unterkircher., V. Fantinato and M.T. Shimizu (2001). Antifungal activity of propolis on different species of candida. Mycoses, 44(9-10): 375-378.

Sarker, M.S.K and C.J. Yang (2010). Propolis and Illite as Feed Additives on Performance and Blood Profiles of Pre-Weaning Hanwoo Calves. Journal of Animal and Veterinary Advances. 9(19): 2526-2531.

SAS Institute Inc., (2004). Procedures Guide for Personal Computer, Statistical Analysis System Institute. Inc., Carry, N.C.

Sharifi, S.D., A. Dibamehr, H. Lotfollahian and B. Baurhoo (2012). Effects of flavomycin and probiotic supplementation to diets containing different sources of fat on growth performance, intestinal morphology, apparent metabolizable energy, and fat digestibility in broiler chickens. Poultry Science (91):918-927.

Stangaciu, S (1999). Apitherapy Internet Course Notes, AIC; 1999. p. 257.

Thickett B., D. Mitchell and B. Hallows (1988). Calf Rearing. $2^{\text {nd }}$ ed. UK: Farming Press. LTD.

Valero, M.V., R.M. Prado., F. Zawadzki., C.E. Eiras., G.S. Madrona and I.N. Prado (2014). Propolis and essential oils additives in the diets improved animal performance and feed efficiency of bulls finished in feedlot. Acta Scientiarum Anim Sci., (36):419 -426.

Van der Bergh, G. (1995). The use of growth promoters in beef production. Pro Agri 3, 22-24.

Van der Merwe, B., J., T.J. Dugmore and K.P. Walsh. (2001). The effect of flavophospholipol (Flavomycin $\circledast$ ) on milk production and milk urea nitrogen concentrations of grazing dairy cows. South African Journal of Animal Science, 31(2): 101-106.

Vynograd, N., I. Vynograd and Z. Sosnowski (2000). A comparative multicentre study of the efficacy of propolis, acyclovir and placebo in the treatment of genital herpes (HSV). Phytomedicine, (7): 1-6.

Wang, N.Z and Li D. (2004). Effect of combined propolis-ethanol-extract and Shaoyao-Gancao-tang on blood sugar Levels in rabbits with alloxan induced experimental diabetes. Asia Pac J Clin Nutr. 13:S66.

Webster, J (1986). Calf husbandry, Health and welfare. London: Reprinted by Collins Proffessional and technical Books.

Yucel, B., A. Onenc., A. Kaya and O. Altan (2015). Effects of Propolis Administration on Growth Performance and Neonatal Diarrhea of Calves. SOJ Veterinary Sciences, 1-5.

Ziaran, H.R., H.R. Rahmani., J. Pourreza (2005). Effect of dietary oil extract of propolis on immune response and broiler performance. Pakistan J. of Biological Sciences, Faisalabad 8 (10):1485. 
تأثثير استخام الفلافوميسين والبروبليز كاضافات علفية على إنتاج اللبن وأداء النمو وتمثيل الام في الجاموس

المصري

محترم عبدالله محمل ابر اهيم و محمج و ائل حسن دغش2

\author{
أقسم الاتتاج الحيوانس_ كلية الزراعة جامعة الازهر بأسيوط - أسيوط - مصر. \\ 2قسم الاتتاج الحيوانى_كلية الزراعة جامعة أسيوط أسيوط - مصر.
}

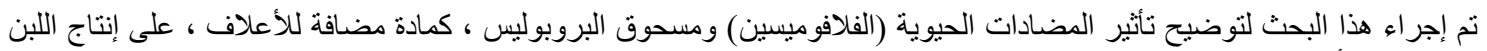

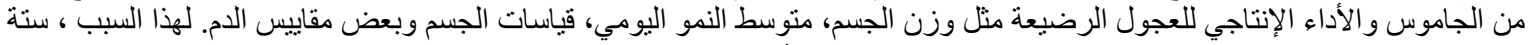

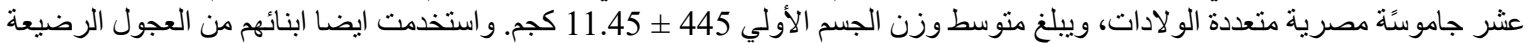

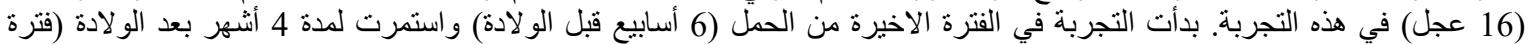

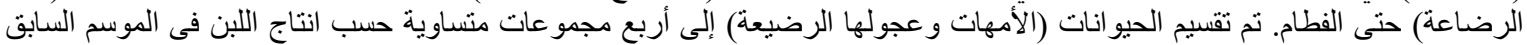

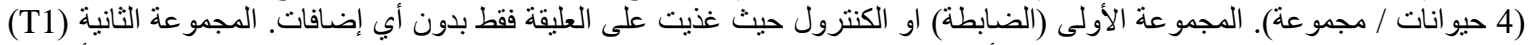

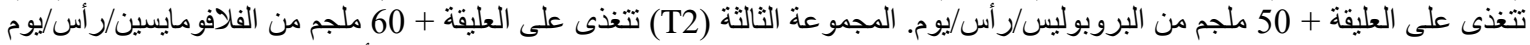

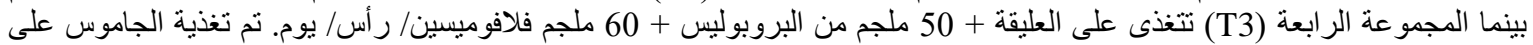

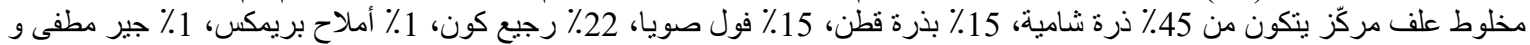

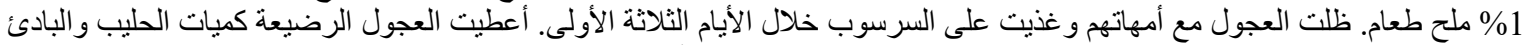

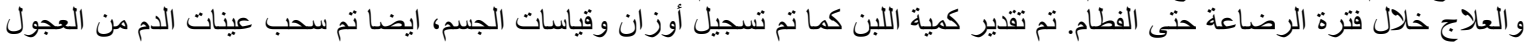

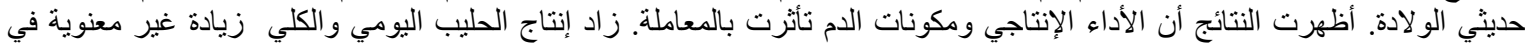

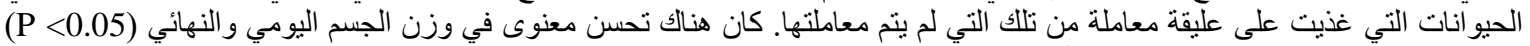

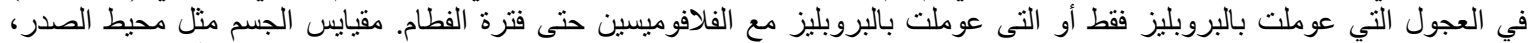

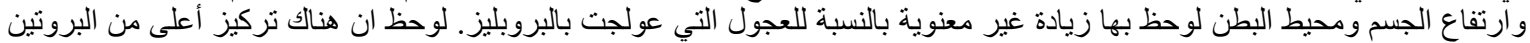

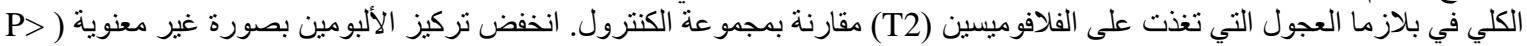

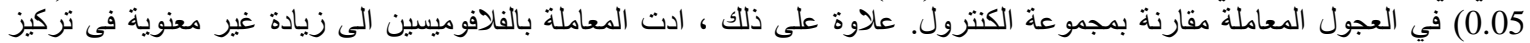

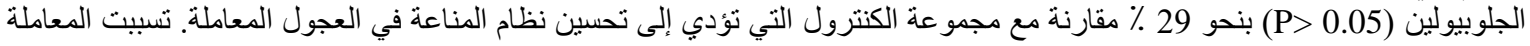

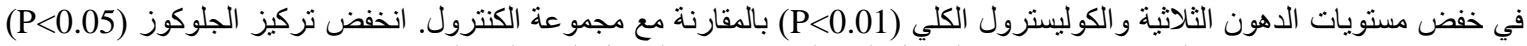

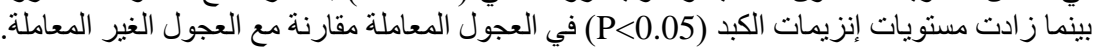

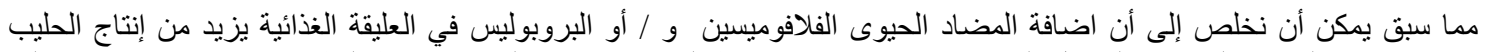

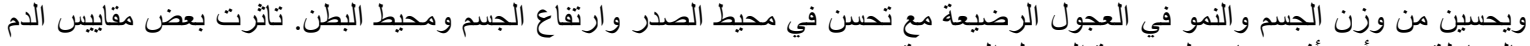
بالمعاملة دون أي تأثير ضار على صحة العجول الرضيعة. 